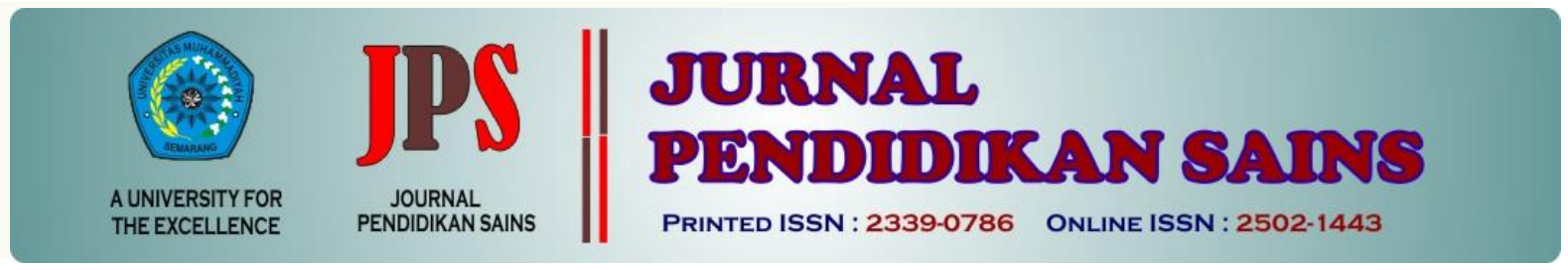

http://jurnal.unimus.ac.id/index.php/JPKIMIA

\title{
PENGARUH SELF EFFICACY, MOTIVASI BERPRESTASI, DAN STUDY HABITS TERHADAP LITERASI SAINS SISWA
}

\author{
Oleh: \\ I Gede Sandi Wiarsana \\ Program Studi S2 Pendidikan IPA, Fakultas Matematika dan Ilmu Pengetahuan Alam, Universitas \\ Pendidikan Ganesha
}

\begin{tabular}{ll}
\hline \multicolumn{2}{l}{ Article history } \\
\hline Submission & $: 2020-04-08$ \\
Revised & $: 2020-07-06$ \\
Accepted & $: 2020-07-14$
\end{tabular}

Keyword:

Kata kunci: science literacy, self efficacy, achievement motivation, study habits

\begin{abstract}
This study aimed to describe effect of self-efficacy, achievement motivation, and study habits to science literacy. This type of study is an ex-post facto design. The population of this study were 3880 students. The selection of school samples is determined by regional sample techniques, 410 students were selected. Data collection using questionnaires and tests. The data was analysed by descriptive analyses and hypotheses was tested by path analyses. The results showed that there were direct effect of self efficacy on science literacy was 0.345. Indirect effect of self efficacy through achievement motivation on science literacy was 0,130. Indirect effect of self efficacy through study habits on science literacy was 0,286. Indirect effect of self efficacy through achievement motivation and study habits on science literacy was 0.139. Direct effect of achievement motivation on science literacy was 0.165 . Direct effect of study habits on science literacy was 0.489 .
\end{abstract}

\section{Pendahuluan}

Pendidikan memiliki peran dalam menunjukkan kualitas sumber daya manusia (SDM) suatu negara. Berdasarkan Muelas dan Navarro (2015), pendidikan yang berkualitas tidak hanya ditentukan oleh penyelenggara pendidikan, tetapi juga oleh siswa karena pendidikan menempatkan siswa sebagai karakter utama dalam proses belajar mengajar. Siswa diharapkan mampu berproses secara aktif dengan mendayagunakan seluruh potensi yang dimiliki dalam membangun pengetahuan, keterampilan, dan sikap sehingga prestasi belajar yang dicapai menjadi lebih optimal. Pencapaian prestasi belajar dan literasi sains siswa yang optimal mencirikan adanya

*Corresponding Author:

$\begin{array}{ll}\text { Nama } & \text { : I Gede Sandi Wiarsana } \\ \text { Lembaga } & \text { : Universitas Pendidikan Ganesha } \\ \text { Email } & \text { : sandiwiarsana@gmail.com }\end{array}$

peningkatan kualitas pendidikan. Pendidikan Sains bertanggung jawab atas literasi sains peserta didik, karena itu kualitas pembelajaran IPA perlu ditingkatkan agar mencapai taraf pengembangan yang berkelanjutan (Liliasari, 2011). Tujuan tersebut akan tercapai apabila didukung oleh pembelajaran yang kondusif serta faktor psikologi siswa. Berdasarkan Widiyanti et al. (2015) mengungkapkan bahwa negara-negara maju sudah membangun literasi sains sejak lama yang pelaksanaannya terintegrasi dalam pembelajaran.

Kenyataannya, berdasarkan hasil Programme for International Student Achievement (PISA) tahun 2015 (OECD, 2015), kualitas literasi sains di Indonesia masih tergolong rendah, dimana menunjukan bahwa 
Indonesia berada di peringkat ke-62 dari 70 negara negara peserta dengan skor rata-rata 403, sedangkan skor rata-rata internasional 500 (OECD, 2015). Selanjutnya pada Human Development Index atau HDI (2016), Indonesia berada dalam posisi 113 dari 188 negara untuk kategori pengembangan sumber daya manusia. Hasil ini menunjukkan bahwa pencapaian kualitas pendidikan di Indonesia masih rendah. Kesenjangan yang terjadi antara upaya dan kenyataan disebabkan oleh banyak faktor yang akan mengakibatkan menurunnya kualitas pendidikan. Beberapa faktor penyebab rendahnya kualitas pendidikan di Indonesia yaitu kurangnya literasi sains siswa, standarisasi yang kurang bermutu, inovasi pendidikan yang kurang berkembang, serta rendahnya prestasi peserta didik (Yuliati, 2017).

Kualitas pendidikan yang rendah tercermin dari literasi sains siswa yang cenderung masih belum optimal, karena literasi sains merupakan hasil nyata yang dapat dijadikan pedoman untuk mengukur kualitas pendidikan di Indonesia (Adams et al., 2014). Menurut Sandhu (2014), terdapat dua faktor yang memengaruhi literasi sains siswa yaitu faktor internal yang berasal dari dalam diri siswa (psikologis) dan faktor eksternal yang berasal dari luar diri siswa. Pada penelitian ini hanya difokuskan pada ranah psikologi atau faktor internal dari siswa itu sendiri yang dapat mempengaruhi literasi sains siswa.

Hasil belajar dan literasi sains yang optimal merupakan tujuan dari proses pembelajaran. Kinerja siswa yang optimal sudah pasti dilakukan oleh siswa dengan sungguh-sungguh dan memiliki self efficacy yang tinggi dalam meraih prestasi. Hal ini tentu menjadi suatu hal yang positif bagi siswa dimana siswa telah memiliki literasi sains yang didasarkan atas self efficacy siswa tersebut. Jika siswa tidak memiliki self efficacy dalam hidupnya maka siswa tersebut tidak akan mampu berkembang dalam meraih prestasi dan cenderung akan merasa pesimis dalam meraih sesuatu. Berdasarkan Sultan et al. (2018), belajar dikontrol oleh aspek internal self efficacy, sehingga dapat dikatakan salah satu faktor psikologis yang berpengaruh terhadap literasi sains siswa salah satunya adalah self efficacy siswa

Ozgen (2013) mengungkapkan bahwa self efficacy memberikan dampak yang positif terhadap pencapaian literasi sains dan prestasi belajar siswa. Individu yang memiliki self efficacy tinggi percaya bahwa mereka dapat secara efektif menangani situasi dan kondisi yang mereka hadapi. Tetap optimis mencapai keberhasilan dalam mengatasi masalah dan berusaha untuk menampilkan ketekunan yang tak kenal lelah (Riyadi \& Efkar, 2018). Alci (2015) dalam penelitiannya juga menemukan bahwa motivasi intrinsik dan self efficacy adalah variabel prediktif untuk literasi sains. Selain itu, berdasarkan penelitian Rosyida et al. (2016), self efficacy secara signifikan berpengaruh langsung terhadap study habits atau kebiasaan belajar dan literasi sains. Self efficacy siswa yang tinggi akan mempengaruhi langsung study habits siswa tersebut. Berdasarkan paparan tersebut, dapat dinyatakan self efficacy memengaruhi motivasi berprestasi, study habits dan literasi sains siswa.

Di sisi lain, motivasi berprestasi juga berpengaruh dalam pencapaian literasi sains serta study habits siswa. Berdasarkan Suresh (2015), mengungkapkan bahwa terdapat hubungan yang positif antara motivasi berprestasi dan study habits terhadap prestasi belajar dan literasi sains peserta didik. Study habits diawali dengan adanya motivasi berprestasi atau keinginan untuk meraih prestasi. Study habits yang baik sulit terlaksana apabila siswa tidak memiliki ambisi dalam meraih sesuatu, ini berarti bahwa study habits diprediksi oleh motivasi berprestasi. Selain itu berdasarkan Atkinson et al. (1966) menyatakan bahwa self efficacy merupakan salah satu aspek yang diperlukan dalam membangun motivasi berprestasi. Berdasarkan Mudjijanti (2013), kondisi siswa yang malas, kurang bergairah dalam belajar, masa bodoh, kurang menyukai tugas yang menantang, lebih suka tugas yang mudah tanpa memerlukan pemikiran merupakan indikasi dari motivasi berprestasi siswa yang rendah. Sebaliknya siswa yang motivasi berprestasinya tinggi tampak dalam perilaku yang rajin, bergairah dalam belajar, aktif, menyukai tugas yang menantang.

Faktor psikologis ketiga yang memengaruhi prestasi belajar dan literasi sains adalah study habits siswa. Literasi sains yang memuaskan hanya dapat dicapai dengan belajar yang tekun, teratur, dan bertahap, artinya keberhasilan belajar yang maksimal dapat dicapai bila siswa memiliki study habits yang baik (O'Neale \& Ogunkola, 2015). Setiap siswa tentu memiliki study habits yang berbeda sehingga akan menghasilkan pengetahuan yang berbeda pula (Chaudhari, 2013). 
Sandhu (2014) juga mengungkapkan bahwa study habits yang kurang baik akan menyebabkan prestasi akademik yang rendah. O’Neale dan Ogunkola (2015) mengemukakan adanya korelasi positif yang signifikan antara study habits dan literasi sains siswa. Semakin baik study habits yang dimiliki siswa, semakin tinggi prestasi akademik yang dicapai, sehingga prestasi akademik dipengaruhi oleh study habits.

Berangkat dari hal tersebut maka peneliti ingin melakukan penelitian dengan judul "Pengaruh Self Efficacy, Motivasi Berprestasi dan Study Habits Siswa terhadap Literasi sains Siswa Kelas VIII SMPN Se-Kota Denpasar”. Alasan melakukan penelitian ini karena berdasarkan hasil-hasil penelitian yang telah dipaparkan, faktor internal siswa memang lebih banyak mempengaruhi literasi sains khususnya self efficacy, motivasi berprestasi, dan study habits. Untuk pengambilan data dilaksanakan di Denpasar karena kemajuan pendidikan atau pembaharuan terhadap sistem pembelajaran lebih dinamis sehingga peningkatan kualitas belajar lebih signifikan terlihat di Denpasar.

Berdasarkan latar belakang, dirumuskan permasalahan diantaranya 1) apakah terdapat pengaruh langsung antara self efficacy siswa terhadap literasi sains siswa kelas VIII pada mata pelajaran IPA di SMP Negeri se-Kota Denpasar? 2) apakah terdapat pengaruh tidak langsung self efficacy siswa melalui motivasi berprestasi terhadap literasi sains siswa kelas VIII pada mata pelajaran IPA di SMP Negeri se-Kota Denpasar? 3) Apakah terdapat pengaruh tidak langsung self efficacy siswa melalui study habits terhadap literasi sains siswa kelas VIII pada mata pelajaran IPA di SMP Negeri se-Kota Denpasar? 4) apakah terdapat pengaruh tidak langsung antara self efficacy melalui motivasi berprestasi dan study habits terhadap literasi sains siswa kelas VIII pada mata pelajaran IPA di SMP Negeri se-Kota Denpasar? 5) apakah terdapat pengaruh tidak langsung antara motivasi berprestasi terhadap literasi sains siswa kelas VIII pada mata pelajaran IPA di SMP Negeri se-Kota Denpasar? 6) apakah terdapat pengaruh tidak langsung antara motivasi berprestasi melalui study habits terhadap literasi sains siswa kelas VIII pada mata pelajaran IPA di SMP Negeri se-Kota Denpasar? 7) apakah terdapat pengaruh langsung study habits terhadap literasi sains siswa kelas VIII pada mata pelajaran IPA di SMP Negeri se-Kota Denpasar? Berdasarkan rumusan masalah tersebut, tujuan penelitian ini akan sejalan dengan mendeskripsikan dan menjelaskan masingmasing rumusan masalah.

\section{Metode Penelitian}

Jenis Penelitian

Jenis penelitian ini adalah penelitian kuantitatif dengan rancangan penelitian ex post facto dengan model statistic path analysis.

Waktu dan Tempat Penelitian

Pelaksanaan penelitian ini selama 3 bulan dari bulan Februari 2019 sampai dengan Mei 2019. Peneliti menggunakan enam sekolah SMP yang tersebar di kota Denpasar yaitu SMPN 1 Denpasar, SMPN 4 Denpasar, SMPN 5 Denpasar, SMPN 7 Denpasar, SMPN 10 Denpasar, dan SMPN 11 Denpasar.

Populasi-Sampel

Populasi dalam penelitian ini adalah siswa kelas VIII SMP di kota Denpasar tahun ajaran 2018/2019 dengan jumlah total 3880 siswa. Pemilihan sampel sekolah menggunakan teknik area sampling sedangkan pemilihan sampel penelitian di setiap sekolah ditentukan dengan teknik proportionate stratified random sampling. Sampel penelitian yang digunakan sebanyak 410 siswa.

Prosedur

Prosedur penelitian ini adalah sebagai berikut. (1) Melakukan observasi awal ke sekolah yang akan dijadikan tempat penelitian. (2) Berdiskusi dengan guru IPA yang ditunjuk mengenai waktu melaksanakan penelitian dan batasan materi yang akan diteliti. (3) Merancang instrumen penelitian yang terdiri atas kuesioner self efficacy, motivasi berprestasi, study habit dan tes literasi sains siswa. (4) Bimbingan instrumen penelitian dengan para ahli yang sudah ditunjuk. (5) Melakukan pengujian instrumen yang akan 
digunakan, sekolah yang dipilih adalah SMP Negeri 1 Denpasar. (6) Melakukan perbaikan (revisi) instrumen. (7) Menentukan sampel penelitian dengan menggunakan teknik simple random sampling. (8) Melakukan pengambilan data. Pengambilan data akan dilakukan setelah materi yang disepakati selesai diajarkan oleh guru pada sekolah yang diteliti. (9) Melakukan analisis data dan pengujian hipotesis yang telah diajukan. (10) Menyusun dan melakukan pelaporan hasil penelitian, pada tahap ini dilakukan pelaporan hasil penelitian berdasarkan analisa statistika.

Data, Intrumen, dan Teknik Pengumpulan Data

Metode pengumpulan data menggunakan instrument berupa kuesioner self efficacy, kuesioner motivasi berprestasi, kuesioner study habits, dan tes literasi sains. Nilai reliabilitas kuesioner self efficacy, kuesioner motivasi berprestasi, kuesioner study habits, serta tes literasi sains secara berturutturut: $0,935,0,933,0,906$, dan 0,608 .

Teknik Analisis Data

Data dianalisis dengan analisis deskriptif dan hipotesis diuji dengan teknik analisis jalur. Gambar 1. menunjukkan model diagram jalur yang ditetapkan oleh peneliti.

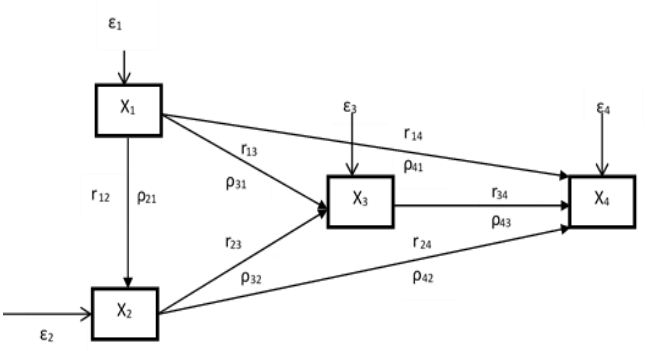

Gambar 1. Model Diagram Jalur Penelitian

Berdasarkan diagram jalur tersebut, $\mathrm{X}_{1}$ adalah self efficacy, $\mathrm{X}_{2}$ adalah motivasi berprestasi, $\mathrm{X}_{3}$ adalah study habits, dan $\mathrm{X}_{4}$ adalah literasi sains siswa.

\section{Hasil Penelitian dan Pembahasan}

Berdasarkan perhitungan, karakteristik data self efficacy siswa kelas VIII SMP Negeri se-Kota Denpasar adalah skor rata-rata (mean) $=155,70$, modus $=159,00$, dan standar deviasi $=26,06$. Perhitungan skor rata-rata self efficacy sebesar 155,70 sehingga kategori data self efficacy siswa adalah "tinggi".
Tabel 1. Rangkuman Statistik Deskriptif Variabel Self Efficacy $\left(\mathrm{X}_{1}\right)$, Motivasi Berprestasi $\left(\mathrm{X}_{2}\right)$, Study Habits $\left(\mathrm{X}_{3}\right)$, dan Tes Literasi Sains Siswa $\left(\mathrm{X}_{4}\right)$

\begin{tabular}{ccccc}
\hline Variabel & $\begin{array}{c}\text { Self } \\
\text { Efficacy }\end{array}$ & $\begin{array}{c}\text { Motivasi } \\
\text { Berprestasi } \\
\left(\mathrm{X}_{2}\right)\end{array}$ & $\begin{array}{c}\text { Study } \\
\text { Habits } \\
\left(\mathrm{X}_{3}\right)\end{array}$ & $\begin{array}{c}\text { Literasi } \\
\text { Sains } \\
\text { Siswa } \\
\left(\mathrm{X}_{4}\right)\end{array}$ \\
\hline Mean & 155,70 & 165,10 & 167,59 & 60,97 \\
\hline Median & 157,00 & 168,00 & 168,00 & 62,00 \\
\hline Modus & 159,00 & 171,00 & 155,00 & 58,00 \\
\hline Maks & 230,00 & 228,00 & 221,00 & 90,00 \\
\hline Min & 90,00 & 90,00 & 103,00 & 32,00 \\
\hline Rentang & 140 & 138 & 118 & 58 \\
\hline Varian & 679,13 & 837,61 & 414,69 & 84,17 \\
\hline SD & 26,06 & 28,94 & 20,36 & 9,18 \\
\hline Mean & 138,00 & 141,00 & 138,00 & 50,00 \\
Ideal & & & & \\
\hline SD Ideal & 30,67 & 31,33 & 30,67 & 16,67 \\
\hline Kategori & Tinggi & Tinggi & Tinggi & Tinggi \\
\hline
\end{tabular}

Karakteristik data motivasi berprestasi siswa kelas VIII SMP Negeri se-Kota Denpasar adalah skor rata-rata $($ mean $)=165,10$, modus $=$ 171,00, dan standar deviasi 28,94. Perhitungan skor rata-rata motivasi berprestasi sebesar 165,10 sehingga data berkategori "tinggi".

Karakteristik data study habits siswa kelas VIII SMP Negeri se-Kota Denpasar adalah skor rata-rata $($ mean $)=167,59$, modus 155,00, dan standar deviasi $=20,36$. Perhitungan skor rata-rata study habits sebesar 167,59 sehingga data berkategori "tinggi".

Karakteristik data literasi sains siswa kelas VIII SMP Negeri se-Kota Denpasar adalah skor rata-rata (mean) $=60,97$, modus 58,00 , dan standar deviasi $=9,18$. Perhitungan skor rata-rata literasi sains siswa sebesar 60,97 dengan kualifikasi "tinggi".

Berdasarkan hasil penelitian tersebut, self efficacy, motivasi berprestasi, dan study habits siswa kelas VIII SMP Negeri Se-Kota Denpasar sudah mampu merangsang dengan kuat terjadinya peningkatan literasi sains siswa. Hal ini diduga karena lingkungan sekolah di Denpasar yang kompetitif akibat dari sistem seleksi masuk sekolah yang menggunakan sistem zonasi atau sistem wilayah, sehingga terjadi pemerataan kemampuan siswa. Dari pemerataan tersebut siswa cenderung ingin berkompetisi untuk menjadi yang terbaik sehingga menimbulkan kompetisi positif antar siswa untuk meningkatkan prestasi belajarnya.

Berikut ini disajikan hasil uji hipotesis dalam bentuk diagram jalur penelitian pada Gambar 2. 


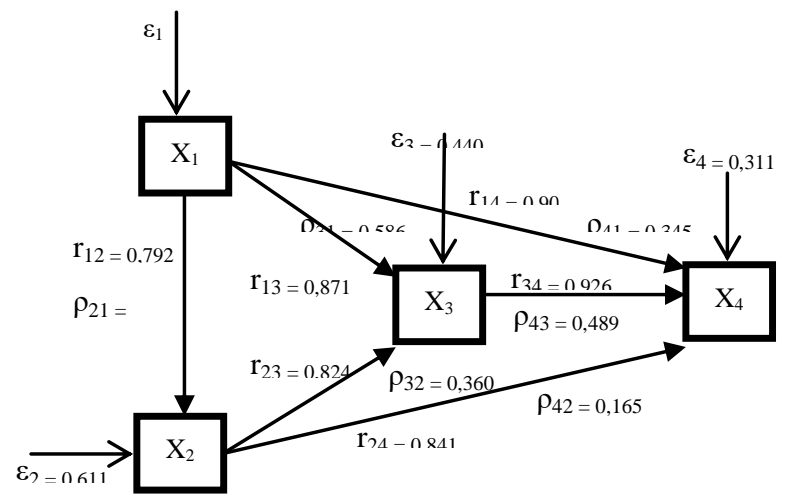

Gambar 2. Diagram jalur Penelitian

Hasil penelitian ini menunjukkan terdapat pengaruh langsung self efficacy terhadap literasi sains siswa dengan nilai pengaruh langsung sebesar $\rho=0,345$ dan signifikansi sebesar $(p<0,05)$. Nilai $\rho=0,345$ bermakna kuatnya pengaruh variabel self efficacy terhadap variabel literasi sains sebesar 0,345 . Hal ini berarti self efficacy siswa memiliki pengaruh langsung secara signifikan terhadap literasi sains siswa SMP se-Kota Denpasar.

Self efficacy yang dimaksud dalam penelitian ini adalah persepsi mengenai kemauan seseorang untuk menghasilkan aksi. Kemauan tersebut merupakan bentuk taraf keyakinan individu terhadap kompetensi dirinya dalam mencapai tujuan.

Self efficacy mengarahkan seseorang untuk menghadapi tantangan yang terjadi dalam kehidupan sehari-hari. (Saraih et al., 2018). Tingkat self efficacy tinggi akan membantu seseorang dalam menciptakan suatu perasaan tenang dalam menghadapi masalah atau aktivitas yang sukar. Seseorang dengan self efficacy rendah akan mudah menyerah, cenderung menjadi stres, depresi, dan mempunyai visi yang sempit tentang apa yang terbaik untuk menyelesaikan masalah itu. Akan tetapi, orang yang memiliki self efficacy yang kuat dalam kompetensi akan mempertahankan usahanya walaupun mengalami kesulitan (Riyadi \& Efkar, 2018).

Siswa dengan self efficacy yang tinggi akan mengatakan bahwa dirinya mampu mempelajari materi yang diberikan di kelas dan memiliki kepercayaan bahwa ia dapat bekerja dengan baik. Siswa yang memiliki self efficacy lebih tinggi akan membantu mereka untuk membangun perasaan tenang dalam menghadapi tugas tertentu. Tingkat self efficacy dapat dianggap sebagai prediktor dari literasi sains siswa (Ismail et al., 2017).

Selain itu, temuan tentang pengaruh langsung antara self efficacy siswa terhadap literasi sains siswa sejalan dengan hasil-hasil penelitian sebelumnya, yaitu: (1) penelitian yang dilakukan oleh Sultan et al. (2018) yang menunjukkan terdapat pengaruh langsung yang signifikan antara self efficacy terhadap literasi sains, dimana untuk mengotimalkan literasi sains salah satunya adalah dengan meningkatkan self efficacy siswa.; (2) penelitian yang dilakukan oleh Taran et al. (2015) menemukan seseorang yang memiliki self efficacy tinggi meyakini bahwa dirinya mampu untuk melakukan aktivitas yang akan dilakukan. Sebaliknya, seseorang yang memiliki self efficacy yang rendah tidak yakin akan kemampuan dalam melaksanakan suatu aktivitas dan ini akan mempengaruhi kemampuan literasi sainsnya.

Berdasarkan hal tersebut, maka hasil penelitian ini memperkuat teori bahwa self efficacy berpengaruh secara langsung terhadap literasi sains siswa. Selain meninjau nilai pengaruh langsung, peneliti juga meninjau pengaruh tidak langsung self efficacy terhadap literasi sains siswa dengan mempertimbangkan keberadaaan faktor lain sebagai variabel intervening /mediating antara self efficacy dan literasi sains siswa.

Pertama, peneliti mengkaji pengaruh tidak langsung self efficacy siswa terhadap literasi sains melalui variabel motivasi berprestasi. Perhitungan koefisien jalur dilakukan secara manual. Jalur yang ditempuh untuk hubungan ini adalah sebanyak dua jalur yaitu jalur self efficacy siswa $\left(\mathrm{X}_{1}\right)$ terhadap motivasi berprestasi $\left(\mathrm{X}_{2}\right)$, kemudian jalur motivasi berprestasi $\left(\mathrm{X}_{2}\right)$ terhadap literasi sains siswa $\left(\mathrm{X}_{4}\right)$. Nilai pengaruh tidak langsung pola self efficacy terhadap literasi sains siswa melalui motivasi berprestasi merupakan hasil perkalian antara koefisien jalur $\mathrm{X}_{1}$ terhadap $\mathrm{X}_{2}$ $\left(\rho_{21}\right)$ dengan koefisien jalur $X_{2}$ terhadap $X_{4}$ $\left(\rho_{42}\right)$. Nilai pengaruh tidak langsung yang diperoleh sebesar 0,130. Diketahui bahwa kedua nilai koefisien jalur yang dikalikan tersebut signifikan $(\mathrm{p}<0,05)$. Hal ini menunjukkan self efficacy memiliki pengaruh tidak langsung secara signifikan terhadap literasi sains siswa melalui motivasi berprestasi siswa SMP se-Kota Denpasar.

Self efficacy erat kaitannya dengan motivasi berprestasi. Tingkat self efficacy seseorang yang tinggi dapat membangkitkan 
motivasi seseorang untuk berjuang menggapai cita-citanya. Orang termotivasi dapat dilihat dari ciri-ciri yang ada pada diri orang tersebut, yaitu tekun mengerjakan tugas, ulet, menunjukkan minat dalam memecahkan masalah, lebih senang bekerja mandiri, selalu ingin mencoba hal baru, mampu mempertahankan argumennya, dan tidak mudah melepaskan hal yang diyakini (Sardiman, 2008).

Adapun temuan relevan terhadap hasilhasil penelitian sebelumnya tentang pengaruh tidak langsung self efficacy terhadap literasi sains melalui motivasi berprestasi siswa yaitu sebagai berikut. (1) Hasil penelitian yang dilakukan oleh Liu dan Cheng (2018) menunjukkan adanya pengaruh langsung dan pengaruh tidak langsung dari self efficacy melalui motivasi berprestasi terhadap literasi sains siswa. Hal tersebut menunjukkan peran meditatif motivasi berprestasi dan strategi pembelajaran terhadap hubungan self efficacy dengan literasi sains. (2) Alci (2015) dalam penelitiannya menemukan aspek self efficacy mahasiswa berpengaruh secara signifikan terhadap motivasi berprestasi. Semakin tinggi self efficacy maka akan diikuti dengan peningkatan motivasi berprestasi siswa, begitu pula sebaliknya.

Berdasarkan paparan di atas, peneliti dapat menyimpulkan bahwa untuk meningkatkan literasi sains siswa, kita sangat perlu memerhatikan self efficacy siswa tersebut. Dengan menggunakan teknik diagram jalur, kita dapat memperoleh besar pengaruh total variabel self efficacy yang terdiri atas pengaruh langsung maupun pengaruh tidak langsung.

Kedua, peneliti mengkaji pengaruh tidak langsung self efficacy terhadap literasi sains siswa melalui variabel study habits. Perhitungan koefisien jalur dilakukan secara manual. Jalur yang ditempuh untuk hubungan ini adalah sebanyak dua jalur yaitu jalur self efficacy $\left(\mathrm{X}_{1}\right)$ terhadap study habits $\left(\mathrm{X}_{3}\right)$, kemudian jalur study habits $\left(\mathrm{X}_{3}\right)$ terhadap literasi sains siswa $\left(\mathrm{X}_{4}\right)$. Nilai pengaruh tidak langsung self efficacy siswa terhadap literasi sains siswa melalui study habits merupakan hasil perkalian antara koefisien jalur $X_{1}$ terhadap $X_{3}\left(\rho_{31}\right)$ dengan koefisien jalur $X_{3}$ terhadap $\mathrm{X}_{4}\left(\rho_{43}\right)$. Nilai pengaruh tidak langsung tersebut adalah 0,286. Diketahui bahwa kedua nilai koefisien jalur yang dikalikan tersebut signifikan ( $<<0,05)$. Hal ini menunjukkan self efficacy siswa memiliki pengaruh tidak langsung secara signifikan terhadap literasi sains siswa melalui study habits siswa SMP se-Kota Denpasar.

Berdasarkan penelitian Sukmawati et al. (2013) dimana self efficacy dan study habits memiliki hubungan yang positif dan signifikan terhadap literasi sains dan prestasi belajar siswa karena kedua hal ini memiliki pengaruh terhadap afeksi perasaan siswa pada saat proses pembelajaran. Dengan demikian dapat dikatakan bahwa semakin tinggi study habits dan self efficacy siswa maka hasil belajar juga baik.

Ketiga, peneliti mengkaji pengaruh tidak langsung self efficacy siswa terhadap literasi sains siswa melalui variabel motivasi berprestasi dan study habits. Perhitungan koefisien jalur dilakukan secara manual. Jalur yang ditempuh untuk hubungan ini adalah sebanyak tiga jalur yaitu jalur self efficacy $\left(\mathrm{X}_{1}\right)$ terhadap motivasi berprestasi $\left(\mathrm{X}_{2}\right)$, kemudian jalur motivasi berprestasi $\left(\mathrm{X}_{2}\right)$ terhadap study habits $\left(\mathrm{X}_{3}\right)$, serta jalur study habits $\left(\mathrm{X}_{3}\right)$ terhadap literasi sains siswa $\left(X_{4}\right)$. Nilai pengaruh tidak langsung self efficacy siswa terhadap literasi sains siswa melalui motivasi berprestasi dan study habits merupakan hasil perkalian antara koefisien jalur $\mathrm{X}_{1}$ terhadap $\mathrm{X}_{2}$ $\left(\rho_{21}\right)$ dengan koefisien jalur $X_{2}$ terhadap $X_{3}$ $\left(\rho_{32}\right)$, serta dengan koefisien jalur $\boldsymbol{X}_{3}$ terhadap $\mathrm{X}_{4}\left(\rho_{43}\right)$. Nilai pengaruh tidak langsung tersebut yaitu 0,139. Diketahui bahwa ketiga nilai koefisien jalur yang dikalikan tersebut signifikan $(\mathrm{p}<0,05)$. Hal ini menunjukkan self efficacy siswa memiliki pengaruh tidak langsung secara signifikan terhadap literasi sains siswa melalui motivasi berprestasi dan study habits siswa SMP se-Kota Denpasar.

Berdasarkan jalur pengaruh self efficacy terhadap literasi sains siswa melalui motivasi berprestasi dan dan study habits, diperoleh nilai pengaruh total self efficacy terhadap literasi sains sebesar 0,139 . Nilai pengaruh ini lebih kecil nilainya dibandingkan nilai pengaruh langsung. Perbedaan nilai antara pengaruh langsung dan pengaruh total dikarenakan self efficacy memang dapat secara langsung memengaruhi literasi sains tanpa memengaruhi variabel lain terlebih dahulu yaitu motivasi berprestasi kemudian study habits. Self efficacy siswa memegang peranan penting dalam membentuk minat, motivasi, dan study habits siswa. Pada penelitian ini dipaparkan bahwa self efficacy tidak hanya memengaruhi prestasi belajar siswa secara langsung melainkan dapat dipengaruhi secara tidak langsung melalui kontribusi dua variabel secara 
bersama yaitu variabel motivasi berprestasi dan study habits.

Temuan tentang pengaruh tidak langsung self efficacy terhadap literasi sains melalui motivasi berprestasi dan study habits siswa sejalan dengan hasil-hasil penelitian sebelumnya, yaitu sebagai berikut. (1) Ghobadi et al. (2016) dalam penelitiannya menemukan bahwa self efficacy memiliki peran penting yang positif untuk memprediksi motivasi berprestasi siswa. (2) Yusuf (2011) juga menemukan self efficacy secara signifikan dapat meningkatkan pencapaian belajar. Self efficacy menentukan bagaimana seseorang merasakan, memikirkan, memotivasi, dan melakukan perbuatan. Berdasarkan hal tersebut, dapat dinyatakan bahwa ketika self efficacy peserta didik meningkat maka prestasi belajar serta literasi sainsnya juga akan meningkat dan begitu pula sebaliknya. Dengan kata lain, self efficacy merupakan prediktor dari motivasi berprestasi dan literasi sains siswa.

Berdasarkan paparan di atas, peneliti dapat menyimpulkan bahwa untuk meningkatkan literasi sains siswa, kita perlu memerhatikan self efficacy siswa. Dengan menggunakan teknik diagram jalur, kita dapat memperoleh besar pengaruh total variabel self efficacy siswa yang terdiri atas pengaruh langsung maupun pengaruh tidak langsung. Selanjutnya, berdasarkan hasil analisis dapat disimpulkan bahwa terdapat pengaruh langsung motivasi berprestasi terhadap literasi sains siswa dengan nilai pengaruh sebesar 0,165 dan signifikansi $(p<0,05)$. Hal ini berarti motivasi berprestasi siswa memiliki pengaruh langsung secara signifikan terhadap literasi sains siswa SMP se-Kota Denpasar.

Motivasi yang paling penting dalam psikologi pendidikan adalah motivasi berprestasi. Menurut McClelland (1987) motivasi berprestasi adalah usaha mencapai sukses atau berhasil dalam kompetisi dengan suatu ukuran keunggulan yang dapat berupa prestasi orang lain maupun prestasi sendiri. Proses pembelajaran yang efektif terbentuk apabila siswa memiliki motivasi yang tinggi. Seseorang dengan motivasi berprestasi tinggi cenderung berjuang untuk mencapai sukses, terutama dalam dunia pendidikan. Siswa yang memiliki motivasi berprestasi akan menyadari bahwa proses pembelajaran merupakan hal yang penting, sehingga kemauan untuk belajar akan datang dari dirinya sendiri, bukan karena terpaksa. Motivasi berprestasi sangat penting dimiliki siswa, sebab dengan keinginan belajar yang kuat, siswa dapat terhindar dari stres.

Kartal dan Kutlu (2017) menyatakan bahwa motivasi berprestasi memiliki korelasi positif yang sangat tinggi dengan literasi sains yang menunjukkan siswa dengan motivasi berprestasi yang lebih baik telah memberikan literasi sains siswa yang lebih baik pula. Siswa yang mempunyai motivasi berprestasi yang baik ditandai dengan beberapa hal yaitu: siswa tersebut berusaha unggul dalam bersaing, menyelesaikan tugas dengan baik, rasional dalam meraih keberhasilan, suka dengan tantangan, dan suka menerima tanggung jawab untuk kepentingan social maupun pribadi.

Selain itu, temuan tentang pengaruh langsung antara motivasi berprestasi terhadap literasi sains siswa relevan dengan hasil-hasil penelitian sebelumnya, yaitu sebagai berikut. (1) Berdasarkan temuan Yazdani dan Godbole (2014) menyatakan bahwa motivasi berprestasi memiliki korelasi positif dengan literasi sains yang menunjukkan siswa dengan motivasi berprestasi yang lebih baik telah memberikan prestasi akademik dan literasi sains yang baik pula. (2) Penelitian yang dilakukan Daniel (2015) menunjukkan bahwa motivasi berprestasi memiliki dampak yang signifikan terhadap literasi sains. Peningkatan literasi sains siswa sejalan dengan peningkatan motivasi berprestasi. Berdasarkan hal tersebut, maka hasil penelitian ini memperkuat teori bahwa motivasi berprestasi berpengaruh secara langsung terhadap literasi sains siswa dan prestasi belajarnya.

Selain meninjau nilai pengaruh langsung, peneliti juga meninjau pengaruh tidak langsung motivasi berprestasi terhadap literasi sains melalui study habits. Perhitungan koefisien jalur dilakukan secara manual. Jalur yang ditempuh untuk hubungan ini adalah sebanyak dua jalur yaitu jalur motivasi berprestasi $\left(\mathrm{X}_{2}\right)$ terhadap study habits $\left(\mathrm{X}_{3}\right)$, kemudian jalur study habits siswa $\left(\mathrm{X}_{3}\right)$ terhadap literasi sains siswa $\left(\mathrm{X}_{4}\right)$. Nilai pengaruh tidak langsung motivasi berprestasi $\left(\mathrm{X}_{2}\right)$ terhadap literasi sains siswa melalui study habits $\left(\mathrm{X}_{3}\right)$ merupakan hasil perkalian antara koefisien jalur $X_{2}$ terhadap $X_{3}\left(\rho_{32}\right)$ dengan koefisien jalur $X_{3}$ terhadap $X_{4}\left(\rho_{43}\right)$. Nilai pengaruh tidak langsung tersebut yaitu 0,176. Diketahui bahwa kedua nilai koefisien jalur yang dikalikan tersebut signifikan ( $\mathrm{p}<0,05)$. Hal ini menunjukkan motivasi berprestasi memiliki pengaruh tidak langsung secara signifikan terhadap literasi sains siswa melalui study 
habits siswa SMP se-Kota Denpasar. Adapun juga pengaruh total motivasi berprestasi terhadap literasi sains siswa sebesar 0,341.

Motivasi berprestasi erat kaitannya dengan study habits. Motivasi berprestasi yang tinggi juga akan berimplikasi pada study habits siswa, dimana berdasarkan hasil penelitian beberapa sumber menyatakan bahwa study habits diawali dengan adanya motivasi berprestasi atau keinginan untuk meraih prestasi.

Di era milenial seperti sekarang ini, sudah banyak siswa yang mempunyai pandangan dan juga mimpi mereka masingmasing dalam berprestasi, hal ini akan menimbulkan perbedaan study habits setiap siswa demi meraih prestasi yang diinginkannya. Jadi study habits yang baik sulit terlaksana apabila siswa tidak memiliki ambisi dalam meraih sesuatu, ini berarti bahwa study habits diprediksi oleh motivasi berprestasi.

Adapun temuan tentang pengaruh tidak langsung motivasi berprestasi terhadap literasi sains siswa melalui study habits yang relevan dengan hasil-hasil penelitian sebelumnya, yaitu sebagai berikut. (1) Hasil penelitian yang dilakukan oleh Suresh (2015) menunjukkan adanya hubungan yang positif antara motivasi berprestasi dan study habits secara bersamasama terhadap prestasi belajar siswa. Study habits diawali dengan adanya motivasi berprestasi atau keinginan untuk meraih prestasi. Study habits yang baik sulit terlaksana apabila siswa tidak memiliki ambisi dalam meraih sesuatu. (2) Mudjijanti (2013) dalam penelitiannya mengungkapkan kondisi siswa yang malas, kurang bergairah dalam belajar, masa bodoh, kurang menyukai tugas yang menantang dan lebih menyukai tugas yang mudah tanpa memerlukan pemikiran merupakan indikasi dari motivasi berprestasi siswa yang rendah. Sebaliknya siswa yang motivasi berprestasinya tinggi nampak dalam perilaku yang rajin, bergairah dalam belajar, aktif, serta menyukai tugas menantang.

Berdasarkan paparan di atas, peneliti dapat menarik benang merah yaitu untuk meningkatkan literasi sains siswa,kita sangat perlu memerhatikan motivasi berprestasi siswa. Dengan menggunakan teknik diagram jalur, kita dapat memperoleh besar pengaruh total variabel motivasi berprestasi yang terdiri atas pengaruh langsung maupun pengaruh tidak langsung.
Selanjutnya, berdasarkan hasil analisis dapat disimpulkan bahwa terdapat pengaruh langsung study habits terhadap literasi sains dengan nilai pengaruh sebesar 0,489 dan signifikansi $(\mathrm{p}<0,05)$. Hal ini berarti study habits memiliki pengaruh langsung secara signifikan terhadap literasi sains siswa SMP seKota Denpasar. Adapun besar pengaruh total variabel motivasi berprestasi terhadap prestasi belajar IPA sama dengan pengaruh langsung karena hanya terdiri dari satu jalur.

Study habits adalah pola belajar yang dilakukan oleh siswa secara teratur dengan teknik yang baik dan waktu belajar yang efektif serta efisien. Study habits yang baik akan dapat meningkatkan prestasi belajar siswa, sebaliknya study habits yang tidak baik cenderung menyebabkan prestasi belajar siswa menjadi rendah (Suresh, 2015). Menurut Crede et al. (2008), study habits adalah pola belajar yang dilakukan oleh siswa, secara teratur, dan terbiasa dengan teknik yang baik dan waktu belajar yang efektif serta efisien, sehingga belajar menjadi kebutuhan.

Selain itu, temuan tentang pengaruh langsung antara study habits terhadap literasi sains siswa relevan dengan hasil-hasil penelitian sebelumnya, yaitu sebagai berikut. (1) Dalam penelitian Yazdani dan Godbole (2014) menunjukkan bahwa study habits secara keseluruhan memiliki korelasi positif yang tinggi dengan literasi sains siswa, sehingga study habits yang baik mengarah pada literasi sains yang lebih baik. (2) Penelitian yang dilakukan oleh Rosyida et al. (2016) menunjukkan bahwa perbedaan hasil belajar siswa dikelas disebabkan oleh perbedaan metode belajar, membaca, dan membuat catatan. Ketiga indikator ini masuk dalam study habits siswa. Jika ketiga indikator tersebut tinggi, maka hasil belajar akan lebih baik.

Study habits sangat berperan penting dalam belajar, dimana keberhasilan belajar atau prestasi belajar yang memuaskan hanya dapat dicapai dengan usaha belajar yang tekun, teratur, dan bertahap. Dengan kata lain, literasi sains dan prestasi belajar yang maksimal dapat dicapai bila siswa memiliki study habits yang baik. Ini mengindikasikan bahwa patut diduga study habits berpengaruh langsung terhadap literasi sains siswa. 


\section{Simpulan dan Saran}

Simpulan

Berdasarkan data dan hasil analisis data, serta pembahasan pada penelitian ini, maka dapat ditarik simpulan sebagai berikut. (1) Terdapat pengaruh langsung self efficacy $\left(\mathrm{X}_{1}\right)$ terhadap literasi sains siswa $\left(\mathrm{X}_{4}\right)$ kelas VIII pada mata pelajaran IPA di SMP se-Kota Denpasar dengan koefisien pengaruh langsung sebesar 0,345. (2) Terdapat pengaruh tidak langsung self efficacy $\left(\mathrm{X}_{1}\right)$ melalui motivasi berprestasi $\left(\mathrm{X}_{2}\right)$ terhadap literasi sains siswa $\left(\mathrm{X}_{4}\right)$ kelas VIII pada mata pelajaran IPA di SMP se-Kota Denpasar dengan koefisien pengaruh tidak langsung sebesar 0,130. (3) Terdapat pengaruh tidak langsung self efficacy $\left(\mathrm{X}_{1}\right)$ melalui study habits $\left(\mathrm{X}_{3}\right)$ terhadap literasi sains siswa $\left(\mathrm{X}_{4}\right)$ kelas VIII pada mata pelajaran IPA di SMP se-Kota Denpasar dengan koefisien pengaruh tidak langsung sebesar 0,286 . (4) Terdapat pengaruh tidak langsung self efficacy $\left(\mathrm{X}_{1}\right)$ melalui motivasi berprestasi $\left(\mathrm{X}_{2}\right)$ dan study habits $\left(\mathrm{X}_{3}\right)$ terhadap literasi sains siswa $\left(\mathrm{X}_{4}\right)$ kelas VIII pada mata pelajaran IPA di SMP se-Kota Denpasar dengan koefisien pengaruh tidak langsung sebesar 0,139 . (5) Terdapat pengaruh langsung motivasi berprestasi $\left(\mathrm{X}_{2}\right)$ terhadap literasi sains siswa $\left(\mathrm{X}_{4}\right)$ kelas VIII pada mata pelajaran IPA di SMP se-Kota Denpasar dengan koefisien pengaruh langsung sebesar 0,165. (6) Terdapat pengaruh tidak langsung motivasi berprestasi $\left(\mathrm{X}_{2}\right)$ melalui study habits $\left(\mathrm{X}_{3}\right)$ terhadap literasi sains siswa $\left(\mathrm{X}_{4}\right)$ kelas VIII pada mata pelajaran IPA di SMP se-Kota Denpasar dengan koefisien pengaruh tidak langsung sebesar 0,176 . (7) Terdapat pengaruh langsung study habits $\left(\mathrm{X}_{3}\right)$ terhadap literasi sains siswa $\left(\mathrm{X}_{4}\right)$ kelas VIII pada mata pelajaran IPA di SMP seKota Denpasar dengan koefisien pengaruh langsung sebesar 0,489.

Saran

Berdasarkan hasil penelitian, pembahasan, dan simpulan, maka dapat diajukan beberapa saran sebagai berikut. (1) Untuk kepala sekolah dapat memberikan mandat kepada guru bimbingan konseling agar menyediakan layanan sharing terkait dengan masalah study habits yang dialami siswa di rumah terutama terkait dengan cara belajar yang efektif dan keterampilan belajarnya. (2) Untuk guru dapat membantu mengembangkan self efficacy siswa secara eksternal melalui persuasi verbal dan penghargaan sosial, hal ini akan meningkatkan dimensi level dan strength pada siswa. Siswa akan mampu memilah tingkat kesulitan dari sebuah tugas, serta akan mampu bersaing dalam menyelesaikan suatu masalah. Motivasi berprestasi siswa dapat dikembangkan dengan beberapa teknik yang memadai, seperti diskusi, pemberian scaffolding serta pemberian reward. Guru dapat memberikan bimbingan konseling kepada siswa terkait permasalahan study habits yang kurang efektif saat dirumah. Guru juga harus memperhatikan dan memahami kajian kurikulum yang tertuang dalam pada silabus guna dapat meningkatkan literasi sains siswa. (3) Untuk orang tua dalam upaya meningkatkan self efficacy, motivasi berprestasi, study habits serta literasi sains siswa, seyogyanya memenuhi kebutuhan anak terutama berupa perhatian yang sekaligus dapat dimanfaatkan untuk membangun kehangatan diantara kedua belah pihak. Perhatian orang tua memberikan dampak terhadap perkembangan sosiokognitif anak. (4) Para remaja khususnya siswa SMP yang masih dalam masa pencarian jati diri. Remaja hendaknya memanfaatkan waktunya untuk lebih banyak berinteraksi dengan orang tua. Tingkatkan jiwa kooperatif dalam diri sehingga lebih termotivasi untuk belajar, saling menguatkan antar teman, dan tujuan pembelajaran dapat tercapai. Remaja yang memiliki self efficacy yang tinggi dalam masyarakat akan mampu mengemban segala tugas yang dilimpahkan kepadanya, salah satunya adalah ikut terjun dalam kegiatan organisasi di banjar. Selain itu, remaja yang memiliki motivasi dan study habits yang positif akan lebih mudah berbaur dengan masyarakat.

\section{Ucapan Terima Kasih}

Penulis mengucapkan terimakasih kepada para dosen di lingkungan Program Studi S2 Pendidikan IPA, Fakultas Matematika dan Ilmu Pengetahuan Alam, Universitas Pendidikan Ganesha atas dukungannya dalam menyelesaikan penelitian ini. Penulis juga berterimakasih kepada pihak-pihak sekolah yang telah mendukung penelitian ini.

\section{Daftar Pustaka}

Adams, B. M., Howard, C., Jolliff, G., \& Myers, J. (2014). Examining the literacy histories of doctoral students in an educational studies program through 
surveys and interviews: A mixed methods study. Journal of the Scholarship of Teaching and Learning, 14(1), 109-125.

Alci, B. (2015). The influence of self-efficacy and motivational factors on academic performance in general chemistry course: A modeling study. Educational Research and Reviews, 10(4), 453-461.

Atkinson, J. W., \& Feather, N. T. (1966). A theory of achievement motivation. New York: Wiley

Chaudhari, A. N. (2013). Study habits of higher secondary school students in relation to their academic achievement. International Journal of Research in Humanities and Socual Sciences, 1(3), 52-54.

Crede, M., \& Kuncel, N. R. (2008). Study habits, skills, and attitudes. Associatiation For Psychological Science, 3(1), 425-453.

Daniel, A. (2015). Influence of achievement motivation and study habits on students academic achievement in Mathematics. Indian Journal Of Applied Research, 5(8), 562-565.

Ghobadi, B., Batmani, S., Mohammadi, Y., \& Batmani, P. (2016). Relationship between parenting styles and self-efficacy with academic achievement's motivation among male students in Sanandaj City. Journal of Administrative Management, Education and Training, 12(4), 202-210.

HDI (Human Development Report Indonesia). (2016). Tersedia pada http://www.id.undp.org/content/ dam/indonesia/2017/doc/INSIndonesia_CountryExplanatory20Note_H DR2016.pdf.

Ismail, M., Aziz, F. H., Fajil, M. F., Ismail, M. F., \& Shah, A. (2017). The relationship between self-efficacy and GPA grade scores of students. International Journal of Applied Psychology, 7(2), 44-47.

Kartal, S. K., \& Kutlu, O. (2017). Identifying the relationships between motivational features of high and low performing stidents and science literacy achievement in PISA 2015 Turkey. Journal of Education and Training Studies, 5(12), 146-154.

Liliasari. (2011). Membangun masyarakat melek sains berkarakter bangsa melalui pembelajaran. Artikel Online. Makalah disampaikan pada seminar nasional UNNES 2011. Tersedia http://liliasari.staf.upi.edu/files/2011/05/M akalah-Semnas-UNNES-2011.Liliasari.pdf
Liu, L., \& Cheng, L. (2018). The relationship between self-efficacy and achievement motivation in adolescents: A moderated mediating model of self-identity and hope. Psychology and Behavioral Sciences, 7(3), 39-46.

McClelland, D. (1987). Human motivation. New York: Cambridge University

Mudjijanti, F. (2013). Pengaruh motivasi berprestasi dan kebiasaan belajar terhadap keberhasilan belajar mahasiswa program studi bimbingan dan konseling tahun akademis 2011/2012. Widya Warta, 2(2), 236-254.

Muelas, A., \& Navarro, E. (2015). Learning strategies and academic achievement. Procedia-Social and Behavioral Sciences, 165, 217-221.

O’Neale, L. G., \& Ogunkola, B. J. (2015). Effect of interest in science, study habits, sex and level of study on the nature of science literacy level of undergraduate chemistry student of the university of the West Indie, Barbados. Journal of Educational and Social Research, 5(2), 267-274.

OECD. (2015). Programme for international student assessment (PISA) 2015. Artikel Online. Tersedia pada https://www.oecd.org/pisa/pisa-2015results-in-focus.pdf.

Ozgen, K. (2013). Self efficacy beliefs in mathematical literacy and connections between mathematics and real world: The case of high school students. Journal of International Education Research, 9(4), 305-316.

Riyadi, T., Sunyono., \& Efkar, T. (2018). Hubungan kemampuan metakognisi dan self efficacy dengan literasi kimia siswa menggunakan model SiMaYang. Jurnal Pendidikan dan Pembelajaran Kimia, 7(2), 251-263.

Rosyida, F., Utaya, S., \& Budijanto. (2016). Pengaruh kebiasaan belajar dan self efficacy terhadap hasil belajar Geografi di SMA. Jurnal Pendidikan Geografi 21(2), 17-28.

Sandhu, S. S. (2014). Academic achievement of adolescents in relation to achievement motivation and study habits. International Multidisciplinary Research Journal, 11(1), $1-10$.

Saraih, U. N., Aris, A. Z. Z., Mutalib, S. A., Ahmad, T. S. T., Abdullah, S., \& Amlus, M. H. (2018). The influence of self- 
efficacy on entrepreneurial intention among engineering students. MATEC Web of Conferences 150, 5(1), 1-6.

Sardiman, A. M. (2008). Interaksi \& motivasi belajar mengajar. Jakarta: Raja Grafindo Persada

Sukmawati, N. P. F., Suarni, N. K., \& Renda, N. T. (2013). Hubungan antara efikasi diri dan kebiasaan belajar terhadap prestasi belajar siswa kelas V SDN di Kelurahan Kaliuntu Singaraja. Artikel Online. Tersedia http://download.portalgaruda.org/article.ph $\mathrm{p}$ ?article $=105368 \& \mathrm{val}=1342$

Sultan, A. I., Henson, H., \& Fadde, P. J. (2018). Pre-service elementary teacher'scientific literacy and self-efficacy in teaching science. IAFOR Journal of Education, $6(1), 25-42$.

Suresh, K. (2015). A study on study habits, achievement motivation and academic achievement of high school student. EPRA Intenational Journal of Economic and Business Review, 3(10), 138-141.

Taran, H., Kalantari, S., Dahaghin, F., \& Abhari, Z. S. (2015). The relationship among parenting styles, self-efficacy, and academic achievement among students. International Journal of Academic Research in Progressive Education and Development, 4(1), 219-222.

Widiyanti, F., Indrianti, D. R., \& Ngabekti, S. (2015). The effectiveness of the application of scientific literacy-based natural science teaching set toward the students learning activities and outcomes on the topic of the interaction of living organism and environment. Indonesian Journal of Science Education, 4(1), 20-24.

Yazdani, K., \& Godbole, V. S. (2014). Studying the role of habits and achievement motivation in improving students' academic performance. European Online Journal of Natural and Social Sciences, 3(4), 827-839.

Yuliati, Y. (2017). Literasi sains dalam pembelajaran IPA. Jurnal Cakrawala Pendas, 3(2), 21-28.

Yusuf, M. (2011). The impact of self-efficacy, achievement motivation, and self-regulated learning strategies on students' academic achievement. Procedia Social and Behavioral Sciences, 15, 2623-2626. 